NASA/TM-2002-211715

\title{
Comparison of ISS Power System Telemetry With Analytically Derived Data for Shadowed Cases
}

H. James Fincannon

Glenn Research Center, Cleveland, Ohio 
Since its founding, NASA has been dedicated to the advancement of aeronautics and space science. The NASA Scientific and Technical Information (STI) Program Office plays a key part in helping NASA maintain this important role.

The NASA STI Program Office is operated by Langley Research Center, the Lead Center for NASA's scientific and technical information. The NASA STI Program Office provides access to the NASA STI Database, the largest collection of aeronautical and space science STI in the world. The Program Office is also NASA's institutional mechanism for disseminating the results of its research and development activities. These results are published by NASA in the NASA STI Report Series, which includes the following report types:

- $\quad$ TECHNICAL PUBLICATION. Reports of completed research or a major significant phase of research that present the results of NASA programs and include extensive data or theoretical analysis. Includes compilations of significant scientific and technical data and information deemed to be of continuing reference value. NASA's counterpart of peerreviewed formal professional papers but has less stringent limitations on manuscript length and extent of graphic presentations.

- TECHNICAL MEMORANDUM. Scientific and technical findings that are preliminary or of specialized interest, e.g., quick release reports, working papers, and bibliographies that contain minimal annotation. Does not contain extensive analysis.

- CONTRACTOR REPORT. Scientific and technical findings by NASA-sponsored contractors and grantees.
- CONFERENCE PUBLICATION. Collected papers from scientific and technical conferences, symposia, seminars, or other meetings sponsored or cosponsored by NASA.

- SPECIAL PUBLICATION. Scientific, technical, or historical information from NASA programs, projects, and missions, often concerned with subjects having substantial public interest.

- TECHNICAL TRANSLATION. Englishlanguage translations of foreign scientific and technical material pertinent to NASA's mission.

Specialized services that complement the STI Program Office's diverse offerings include creating custom thesauri, building customized data bases, organizing and publishing research results ... even providing videos.

For more information about the NASA STI Program Office, see the following:

- Access the NASA STI Program Home Page at http://www.sti.nasa.gov

- E-mail your question via the Internet to help@sti.nasa.gov

- Fax your question to the NASA Access Help Desk at 301-621-0134

- Telephone the NASA Access Help Desk at 301-621-0390

- Write to:

NASA Access Help Desk

NASA Center for AeroSpace Information 7121 Standard Drive

Hanover, MD 21076 
NASA/TM-2002-211715

IECEC-2002-20113

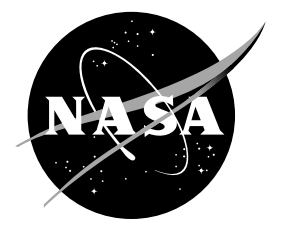

\section{Comparison of ISS Power System Telemetry With Analytically Derived Data for Shadowed Cases}

H. James Fincannon

Glenn Research Center, Cleveland, Ohio

Prepared for the

37th Intersociety Energy Conversion Engineering Conference sponsored by the Institute of Electrical and Electronics Engineers, Electron Devices Society

Washington, DC, July 28-August 2, 2002

National Aeronautics and

Space Administration

Glenn Research Center 


\section{Acknowledgments}

The author thanks Silvia Stewart from the NASA JSC Video Repository for help in acquiring ISS video and NASA GRC's Thomas Kerslake for solar array current telemetry conversion formulae and expertise.

Available from

NASA Center for Aerospace Information 7121 Standard Drive

Hanover, MD 21076
National Technical Information Service 5285 Port Royal Road Springfield, VA 22100

Available electronically at http:/ /gltrs.grc.nasa.gov 


\title{
COMPARISON OF ISS POWER SYSTEM TELEMETRY WITH ANALYTICALLY DERIVED DATA FOR SHADOWED CASES
}

\author{
H. James Fincannon \\ National Aeronautics and Space Administration \\ Glenn Research Center \\ Cleveland, Ohio 44135 \\ Phone: $216-433-5405$ \\ Fax: 216-433-2995 \\ E-mail: Fincannon@grc.nasa.gov
}

\begin{abstract}
Accurate International Space Station (ISS) power prediction requires the quantification of solar array shadowing. Prior papers have discussed the NASA Glenn Research Center (GRC) ISS power system tool SPACE (System Power Analysis for Capability Evaluation) and its integrated shadowing algorithms. On-orbit telemetry has become available that permits the correlation of theoretical shadowing predictions with actual data. This paper documents the comparison of a shadowing metric (total solar array current) as derived from SPACE predictions and onorbit flight telemetry data for representative significant shadowing cases. Images from flight video recordings and the SPACE computer program graphical output are used to illustrate the comparison. The accuracy of the SPACE shadowing capability is demonstrated for the cases examined.
\end{abstract}

\section{INTRODUCTION}

In December 2000, the first ISS U.S. photovoltaic power system (designated as P6) was deployed. Because of its size, some of the largest shadow patterns ever observed on orbital solar arrays ( 170 $\mathrm{m}^{\wedge} 2$ ) have occurred. Shadow patterns with significant durations, varied distributions and shapes appeared on the arrays. Significant shadowing events happened during normal flight operation and transient events such as STS (Space Transportation SystemSpace Shuttle) fly-around survey, flight mode transition, vehicle docking/undocking, waste water dumps, reboost, extravehicular activity (EVA) and assembly operations free drift. As ISS modules are added, power demands increase, especially during assembly, and shadowing events increase in frequency and magnitude in a complex fashion that can only be predicted using computer programs.

Analysis tools have been developed to predict the impact of shadowing on the ISS power system. Prior papers have discussed the development of these tools (SPACE and its integrated shadowing algorithms) (Hojnicki, 1993) (Kerslake, 1993a) (Fincannon, 1996) and analysis results using them (Fincannon, 1995, 1999, 2002). SPACE models all required hardware and integrates all necessary analysis components to determine the time-varying effect of load demand on the power system.

Because of SPACE's importance to ISS, measures are taken to validate its various component parts. Its shadowing algorithms and geometry models have been validated manually for simple cases during the ISS Verification Analysis Cycles. Successful comparisons have also been made with shadowing analyses from Russia's NPO Energia, Boeing and the NASA JSC Mission Operations Directorate (each using a different approach and/or implementation). Given available P6 telemetry and video footage, it is feasible to compare SPACE power system predictions with the on-orbit data.

This comparison is of particular interest because the shadowing algorithms and geometry data necessitated key assumptions. These assumptions were that 1) relatively low fidelity geometry models were acceptable, 2) Sun subtense angle effects were minimal, and 3) reflected energy from adjacent hardware was minimal. Of these, the geometry model was the main concern. SPACE geometry models are a specially created lower fidelity derivation $(<2000$ polygons) of highly detailed ISS models $\left(>10^{\wedge} 6\right.$ polygons). Lower fidelity increases computational speed for the integrated shadowing analysis and reduces memory limitations. Variations in dimensions (due to structural/thermal distortion, thermal blankets, etc), missing hardware omitted in fidelity reduction, unknown hardware modes (retraction or deployment) are examples of areas of concern regarding model accuracy. Quantifying the amount of these effects is an important outcome of the comparison process. 


\section{VIDEO OBSERVATIONS}

P6 solar arrays are primarily videotaped from the STS payload bay cameras. Video recordings acquired at the GRC Engineering Support Room and the NASA Johnson Space Center (JSC) Video Repository were examined for shadow images. The video covered a period from STS-97/ISS Flight 4A to STS-105/ISS Flight 7A.1 (250 days and 6 assembly flights). During this period, the primary shadowinducing hardware onto the P6 solar arrays were the P6 thermal radiators, STS, Progress resupply module (aft of Zvezda), Zvezda and Zarya solar arrays. Other qualitative observations include 1) most shadowing video was from moderate absolute solar beta angles or below (<37 degrees), 2) shadowing occurred primarily on one wing during an orbit and 3) large shadows appeared dark and hard edged with no apparent reflections of adjacent hardware.

\section{CASE SELECTION METHOD}

For the time period from P6 solar array deployment until one year later, the ISS had traveled through over 5500 orbits, with solar beta angles ranging from 73 to -73 degrees, various flight attitudes/methods, solar array pointing, and STS docking locations. Since most orbits had some shadowing and analyzing every orbit is time prohibitive, criteria had to be developed to filter the cases to those most illustrative in a comparison.

\section{Video Imagery}

Although frequent shadowing occurs when there is no video recording taking place, due to the difficulty in understanding the shadow patterns with the limited ISS telemetry, it was desired to coincide the telemetry with actual video footage. Video is used to qualitatively verify the shadow patterns and understand geometry nuances. Quantitative matching of the SPACE and video shadow patterns is difficult and time-consuming because of camera orientation, camera panning, camera zooming, perspective and changing solar array angles.

\section{Adequate Telemetry}

Cases with video footage required that adequate telemetry be available for the period. Most orbits have telemetry dropouts (due to antenna blockage or other communication problems) of various durations. Complex maneuvers and gimbal activities with even brief dropouts may lose enough information to make the case impractical for comparisons.

\section{Sufficient Shadow Current Drop}

Because of the presence of uncertainty (e.g., albedo, solar array temperature) in the analysis, cases with high shadowing-related current drops ( $>25 \%$ of unshadowed) were required to overwhelm these factors, thus depicting primarily shadowing effects.

\section{TELEMETRY PROCESSING}

Acquiring telemetry data and correlating it with predictions is complicated due to data drop outs, lack of synchronized reporting of data elements, sensor calibration, data conversion, and un-sensored data. Solar array current telemetry is only available at the solar array wing level, not the string level. Telemetry was obtained for the shunted and unshunted solar array string currents for each solar array wing (there are two wings on P6, two blankets per wing). Calibration formulae based on ground test data were applied to the solar array current sensor telemetry to improve their accuracy (they are typically too low by a total current value of about $2 \%$ per wing).

Telemetry from the shunted solar array strings were adjusted to represent unshunted strings. Solar array string shunting is performed to regulate the power distribution. Shunted current telemetry was adjusted in two ways: 1) The shunted current measured during string shadowing was reduced to account for the difference in shunted and operating string current dependencies. [For low shunted string voltage drops (e.g., the result of shadowed cells in a string not contributing voltage), shunt current is largely insensitive to cell operating voltage due to the cell current-voltage (IV) characteristic curve between the short circuit and maximum power points. Conversely, a high voltage, illuminated string current (e.g., unshunted strings) is very sensitive to cell operating voltage (as affected by shadowed cells in a string not contributing voltage) since the cell IV curve changes dramatically between the maximum power and open circuit points.] 2) The remaining current was reduced by a factor (0.9) representing shunted string higher temperature operation, operating current difference and voltage difference.

\section{COMPARISON RESULTS}

Descriptive data for each case is provided below. Attitude is specified in terms of (Yaw, Pitch, Roll) or $(Y, P, R)$ in degrees. Only XvvZnadir flight mode cases were examined. Here, the ISS $+X$ axis is in the velocity vector, the $+Z$ axis in the nadir direction, the $+Y$ axis on the right/starboard side (with observer's feet at nadir and facing in $+X$ direction) and $-Y$ axis on the 'port' side. The solar array wing designated '2B' is on the starboard side and '4B' on the port side. Note that Yaw is about $Z$, Pitch about $Y$, and Roll about X.

To bound the variable, several orbit-constant albedo (abbreviated as 'ALB' in the figures) values were assumed. Nominally, the average albedo of $27 \%$ was used. In addition, a 'high' albedo of $40 \%$ and a 'low' albedo of $15 \%$ were used when warranted. Albedo contributes significantly to power production but its actual value (which changes through the orbit) is not known for the following cases. Historical averages are normally used but seasonal/ geographic/weather variations and albedo shadowing 
give it a broad uncertainty. Short term albedo varies from 0.05 to 0.60 .

Each figure shows the solar array current based on telemetry and the SPACE prediction, selected representative video frames and SPACE graphical output (Sun's eye view cartoon and projected shadow pattern of wing of interest). Synchronization of video and SPACE output is difficult due to rapid changing shadow patterns. However, in general, these showed a good relative comparison for each case.

To aid in understanding the amount of shadowing relative to the total amount of available solar array current, a quantity called Shadowing_Impact was calculated. This value was the percent reduction caused by shadowing of the combined solar array amp-hours for both wings. To quantify the difference between the telemetry and prediction current values, a quantity called Shadowing_Difference was calculated. To determine this value, the solar array currents for prediction and telemetry were summed (averaged and time-weighted) for only the time period when the solar array is shadowed (to eliminate other variables). The percent difference between prediction and telemetry provided the Shadowing_Difference. Note that this value was determined only for the solar array that was most shadowed. The resulting value represents the net amp-hour difference between the actual value and the SPACE prediction, a more important measure than instantaneous current differences (with regards to energy balance).

\section{ISS Flight 4A (12/8/2000)}

The P6 solar arrays were added in this flight (Figure 1). Insolation began at 18:57 GMT with a solar beta angle of 28.4 degrees and altitude of 374 $\mathrm{km}$. Both solar arrays were locked. Insolation began with a pitch of YPR $(3,147,-4)$ which peaked at YPR $(0,160,-3)$ but drifted back down to YPR $(0,8,3)$ by the end of insolation. This attitude change was due to a free drift mode during a radiator loads validation test. At orbit dawn, the backside of one solar array wing was shadowed by the STS and forward $(+X)$ ISS radiator. The remainder of the orbit was unshadowed. This case had $62 \%$ shadowing of one wing $\left(\sim 170 \mathrm{~m}^{\wedge} 2\right)$. Because the front of the solar array was facing toward Earth early in the orbit, it was more sensitive to albedo variation. Examination of satellite images and ground tracks showed that heavy cloud cover during the early part of the orbit justified an albedo higher than the average. This case had Shadowing_Impact of $3 \%$. This case had a Shadowing_Difference of $20 \%$ below telemetry for average albedo and $2 \%$ below telemetry for high albedo.

\section{ISS Flight 6A (4/28/00)}

During remote manipulator assembly operations activity, significant shadowing occurred early in the orbit (Figure 2) while the remainder was unshadowed. Insolation began at 15:15 GMT with a solar beta angle of -27.5 degrees, altitude of $392.7 \mathrm{~km}$ and flight attitude of YPR $(0,23,0)$. Solar arrays were fully tracking. Shadowing by the P6 radiator and STS-100 occurred on previous and subsequent orbits. Reasonable variation of albedo had minimal effect on the results so only the average case is presented. This case had a Shadowing_Impact of a $2 \%$. This case had a Shadowing_Difference of $4 \%$ above telemetry.

\section{ISS Flight 7A.1 (8/14/01)}

Prolonged significant shadowing occurred during a maneuver into reboost (by the STS-105) attitude (Figure 3). The solar arrays were fully sun-tracking except for Zvezda's arrays which were locked. Insolation began at 17:04 GMT with a solar beta angle of 14.6 degrees and altitude of $394.9 \mathrm{~km}$. The attitude started at YPR $(0,23.8,0)$, then transitioned in pitch to YPR $(2,-122,3)$. This resulted in the ISS being upside-down and backwards from its normal flight attitude. This case had the highest relative shadowing with a Shadowing_Impact of $6 \%$. This case had a Shadowing_Difference of 6\% above telemetry. The main deviation occurred at the point when the Zvezda solar array shadow passes between the P6 blankets. Since the telemetry was not continuous, this transient current increase was missed. Note that removal of the one point reduced the differences to $3 \%$ and $5 \%$ respectively. Reasonable variation of albedo had minimal effect on the results so only the average case was presented.

\section{ISS Flight 5A (2/16/01)}

After the STS undocks, the video/photographic inspection of ISS called fly-around starts at orbit dawn and continues until orbit dusk. Fly-around shadowing is important because the distance of the shadowing object enhances Sun subtense angle effects. Implementation of fly-around depends upon STS docking location. The variables for fly-around include the STS displacement (X,Y and Z) from ISS, the rate and starting time. Fly-around is assumed to occur with the STS passing in a circle around the ISS in the orbit plane (X-Z plane) from ISS-forward to ISS-zenith then to ISS-aft. The orientation of the STS is held such that the STS payload bay is always pointing toward the ISS. Because of variable STS passage rates (4-8 degrees/minute), it was assumed the rate at shadow occurrence happened throughout flyaround with the start time adjusted to reflect this fact.

Insolation began at 14:24 GMT (Figure 4) with a solar beta angle of -2.5 degrees, altitude of $382 \mathrm{~km}$ and flight attitude of YPR $(10,-10,0)$. The gimbals started in a locked position for undocking and then transitioned to sun tracking prior to the start of shadowing. For this stage, the STS was docked in the ISS nadir location the tail of the STS facing in the ISS velocity vector. Upon undocking, the STS moved away along the ISS $+Z$ axis towards Earth. At 120150 meters (130 meters at shadow time), the STS loitered until orbit dawn. Then, the STS "backed-up" around ISS. The STS was offset from the ISS coordinate center by 6 meters in the $-Y$ direction. This case had a Shadowing_Impact of $2 \%$. This case 
had a Shadowing_Difference of $4 \%$ above telemetry for low albedo and $8 \%$ above telemetry for average albedo.

\section{ISS Flight 7A.1 (8/20/01)}

Insolation began at 14:51 GMT (Figure 5) with a solar beta of -12.6 degrees and altitude of $396 \mathrm{~km}$. The flight attitude transitioned from YPR $(3,22,2)$ to YPR $(-5,7,0)$. The STS-105 was docked to the Lab forward PMA2 location, with its tail in the nadir direction and bottom in the velocity vector direction. The STS departed by moving away along the positive ISS $X$ axis. Fly-around proceeded at dawn with the STS nose-first. This case had $62 \%$ shadowing of one wing $\left(\sim 170 \quad \mathrm{~m}^{\wedge} 2\right)$. This case had a Shadowing_Impact of $2 \%$. This case had a Shadowing_Difference of $2 \%$ below telemetry for low albedo and $1 \%$ above telemetry for average albedo.

\section{CONCLUSION}

This paper compared a subset of the available ISS telemetry data with SPACE predictions. Caveats of this analysis were that temperature effects could not be properly assessed due to lack of telemetry and albedo data could not be definitively quantified. Although shadowing effects caused by all ISS hardware under all orbital conditions could not be considered, for the cases that were examined, the SPACE shadowing algorithms and geometry models predicted shadowing effects at acceptable difference levels from telemetry (within $6 \%$ of solar array wing amp-hour capability during a shadowing event). Comparisons of back and front side solar array shadowing of solar illumination were presented. Sun subtense angles effects, even with distant shadowing objects, were not discernable. The effect of reflections on shadow patterns was not apparent using video imagery or telemetry. The remaining comparison amp-hour differences are likely due to a combination of geometric model fidelity (primarily) and Sun subtense angle effects.

\section{REFERENCES}

Fincannon, J., 1995, "Analysis of Shadowing Effects on Spacecraft Power Systems," NASA TM106994, Cleveland, $\mathrm{OH}$.

Fincannon, J., et al., 1996, "Load-Following Power Timeline Analyses for the International Space Station," NASA TM-107263, Cleveland, OH.

Fincannon, J., et al., 1999, "Effects of Solar Array Shadowing on the Power Capability of the Interim Control Module," NASA TM-209378, Cleveland, OH.

Fincannon, J., 2002, "Incident Energy Focused Design and Validation for the Floating Potential Probe," NASA TM-211349, Cleveland, OH.

Hojnicki, J.S., and Kerslake, T.W., 1993, "Space Station Freedom Electrical Performance Model," NASA TM-106395, Cleveland, OH.

Kerslake, T.W., and Hojnicki, J.S., 1993a, "System Performance Predictions For Space Station Freedom's Electrical Power System," NASA TM106396, Cleveland, $\mathrm{OH}$.

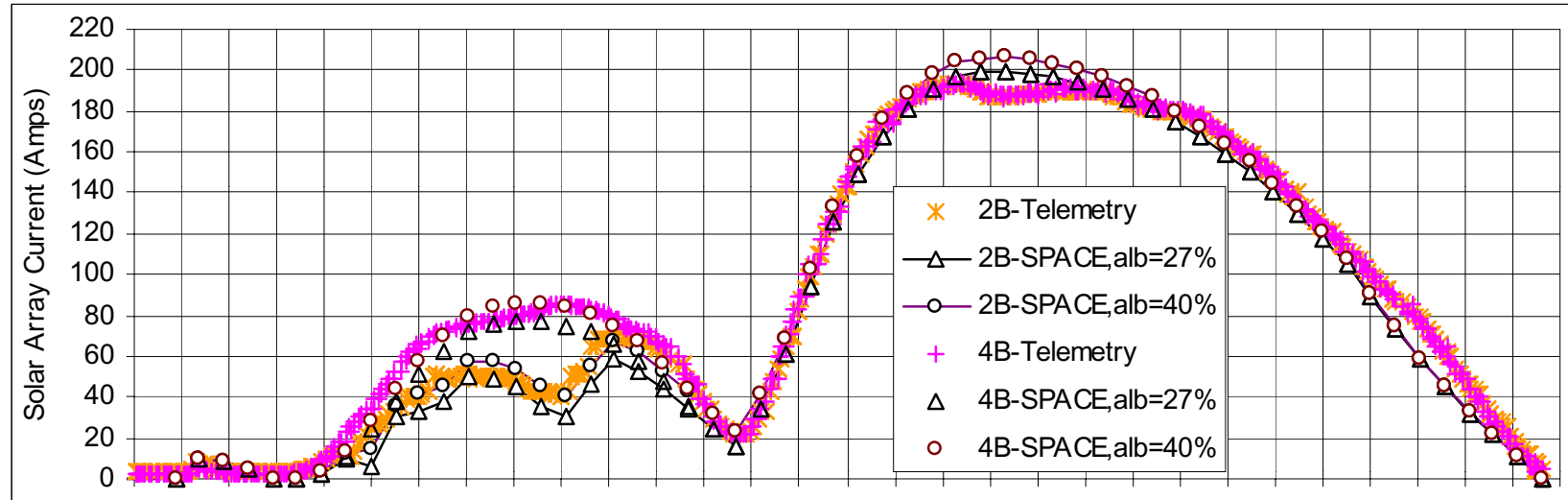

$\begin{array}{lllllllllllllllllllllllllllllll}33 & 35 & 37 & 39 & 41 & 43 & 45 & 47 & 49 & 51 & 53 & 55 & 57 & 59 & 61 & 63 & 65 & 67 & 69 & 71 & 73 & 75 & 77 & 79 & 81 & 83 & 85 & 87 & 89 & 91 & 93\end{array}$

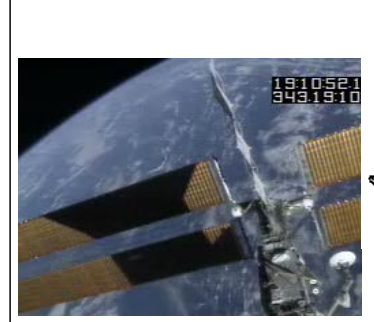

$49 \mathrm{~min}$

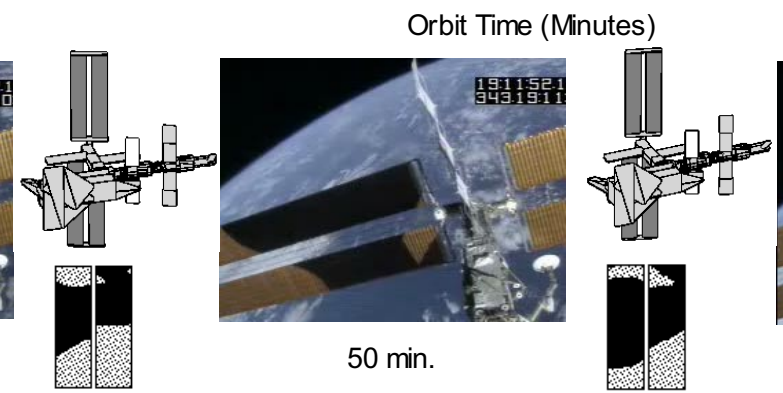

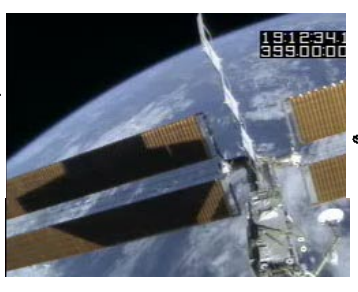

$51 \mathrm{~min}$.

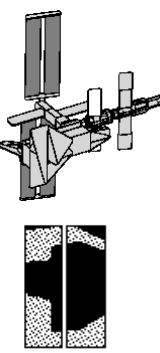

FIGURE 1: ISS FLIGHT 4A FREE DRIFT- SOLAR ARRAY CURRENT, SPACE GRAPHICS AND VIDEO FRAMES 


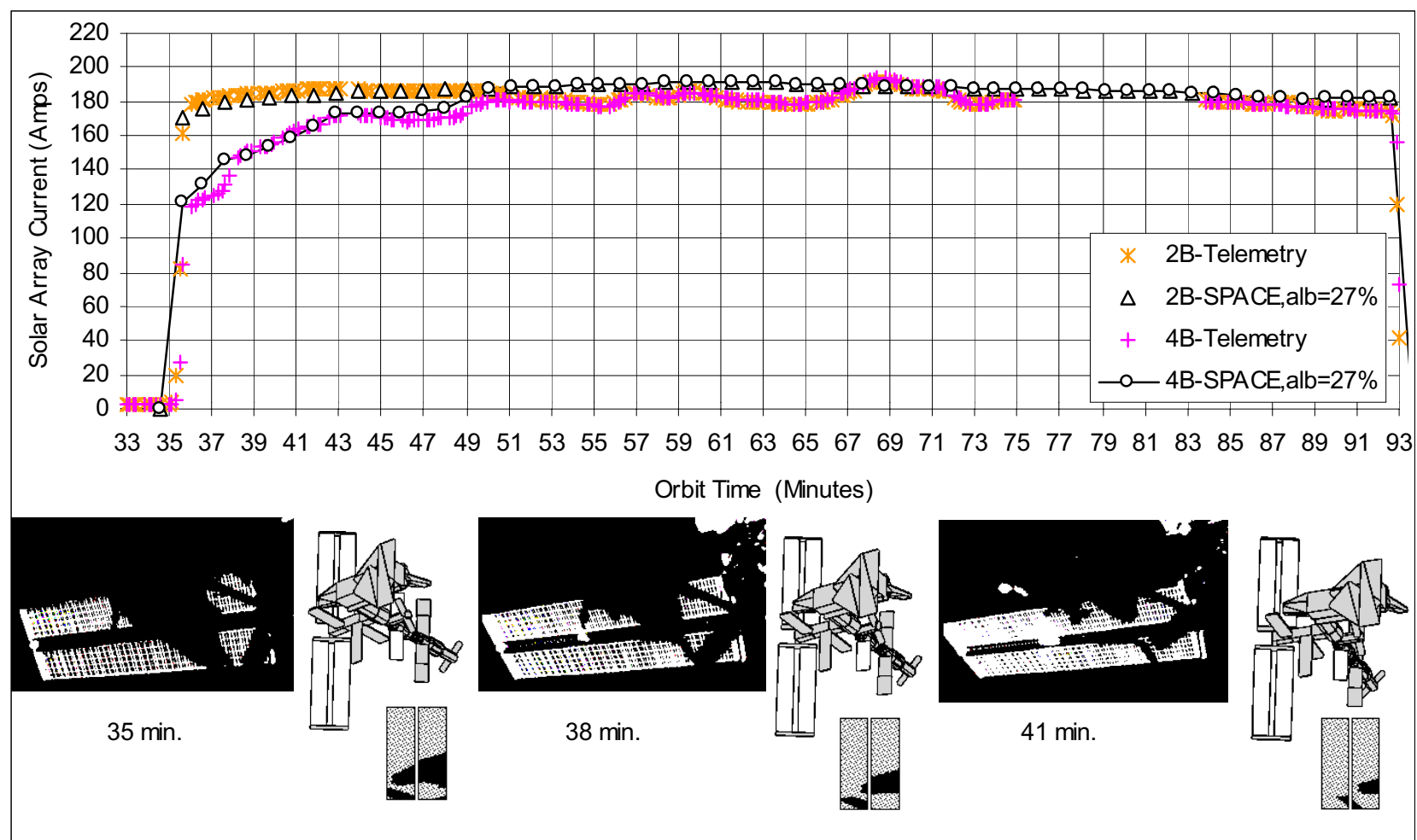

FIGURE 2: ISS FLIGHT 6A ASSEMBLY- SOLAR ARRAY CURRENT, SPACE GRAPHICS AND VIDEO FRAMES

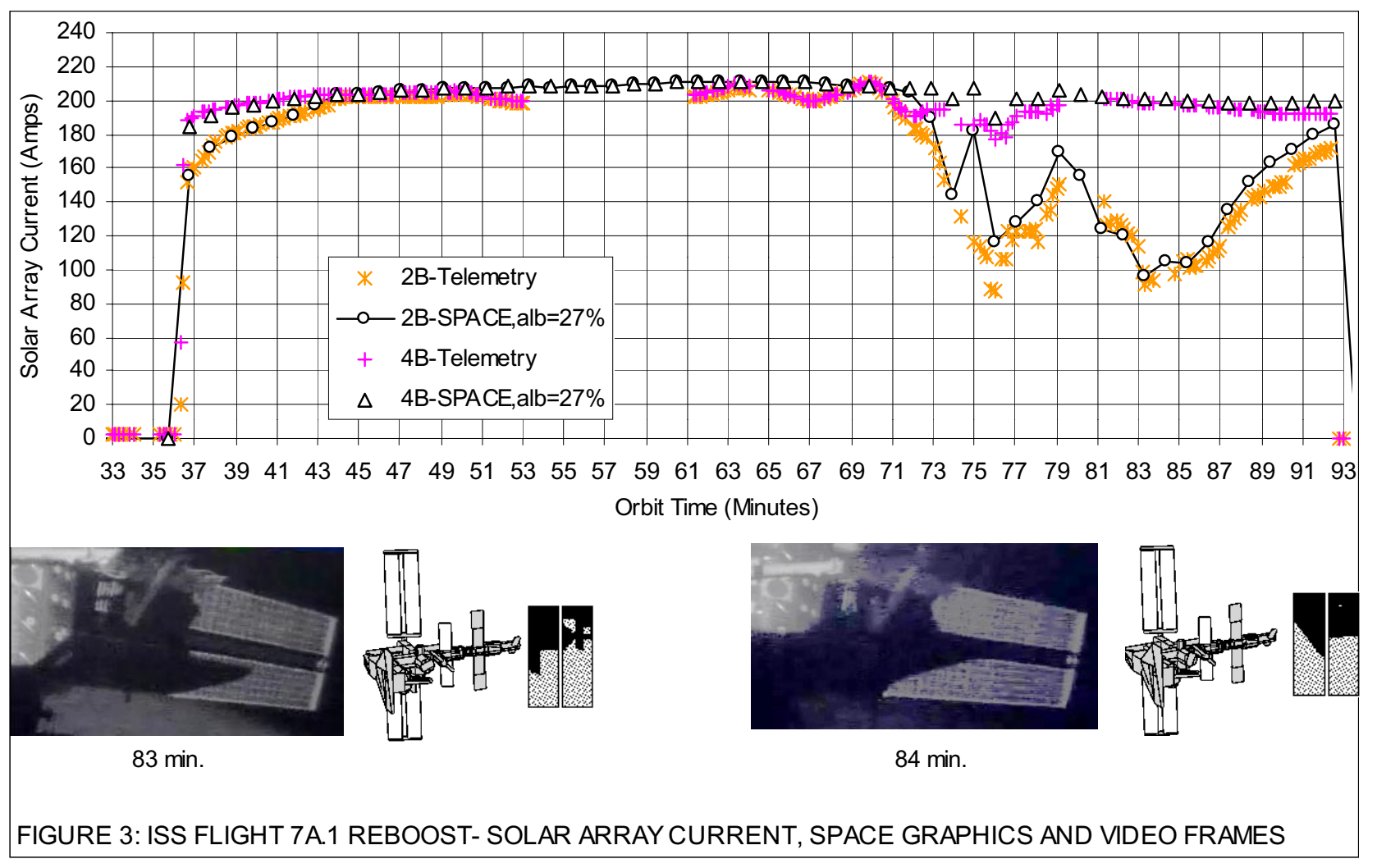



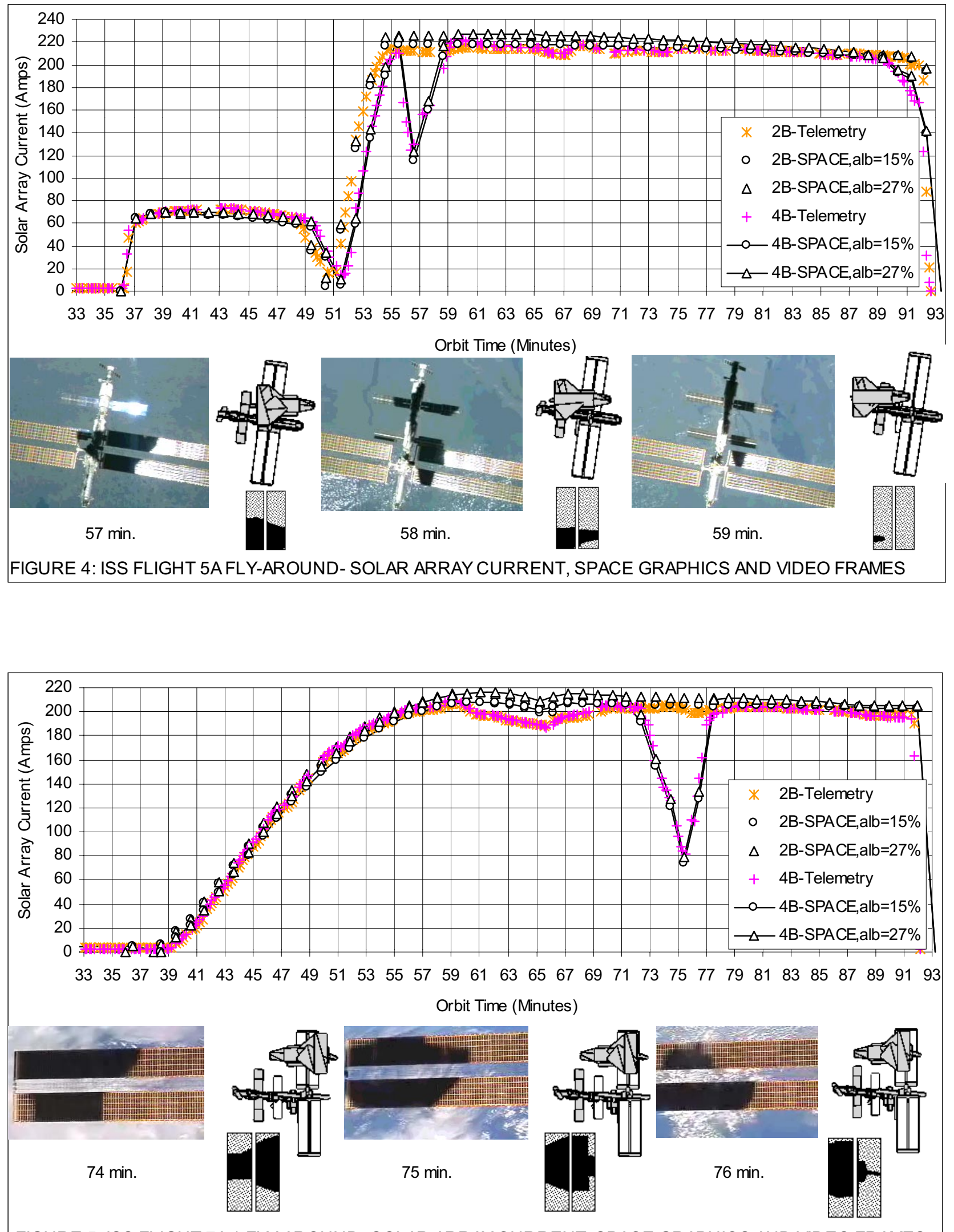

FIGURE 5: ISS FLIGHT 7A.1 FLY-AROUND- SOLAR ARRAY CURRENT, SPACE GRAPHICS AND VIDEO FRAMES 


\begin{tabular}{|c|c|}
\hline \multicolumn{2}{|c|}{ REPORT DOCUMENTATION PAGE } \\
\hline \multicolumn{2}{|c|}{$\begin{array}{l}\text { Public reporting burden for this collection of information is estimated to average } 1 \text { hour per response, including the time for reviewing instructions, searching existing data sources, } \\
\text { gathering and maintaining the data needed, and completing and reviewing the collection of information. Send comments regarding this burden estimate or any other aspect of this } \\
\text { collection of information, including suggestions for reducing this burden, to Washington Headquarters Services, Directorate for Information Operations and Reports, } 1215 \text { Jefferson } \\
\text { Davis Highway, Suite 1204, Arlington, VA 22202-4302, and to the Office of Management and Budget, Paperwork Reduction Project (0704-0188), Washington, DC } 20503 \text {. }\end{array}$} \\
\hline 1. AGENCY USE ONLY (Leave blank) & $\begin{array}{r}\text { 2. REPORT DATE } \\
\text { July } 2002\end{array}$ \\
\hline \multicolumn{2}{|c|}{$\begin{array}{l}\text { 4. TITLE AND SUBTITLE } \\
\text { Comparison of ISS Power System Telemetry With Analytically Derived Data } \\
\text { for Shadowed Cases }\end{array}$} \\
\hline \multicolumn{2}{|l|}{$\begin{array}{l}\text { 6. AUTHOR(S) } \\
\text { H. James Fincannon }\end{array}$} \\
\hline \multicolumn{2}{|c|}{$\begin{array}{l}\text { 7. PERFORMING ORGANIZATION NAME(S) AND ADDRESS(ES) } \\
\text { National Aeronautics and Space Administration } \\
\text { John H. Glenn Research Center at Lewis Field } \\
\text { Cleveland, Ohio } 44135-3191\end{array}$} \\
\hline \multicolumn{2}{|c|}{$\begin{array}{l}\text { 9. SPONSORING/MONITORING AGENCY NAME(S) AND ADDRESS(ES) } \\
\text { National Aeronautics and Space Administration } \\
\text { Washington, DC 20546-0001 }\end{array}$} \\
\hline
\end{tabular}

Prepared for the 37th Intersociety Energy Conversion Engineering Conference sponsored by the Institute of Electrical and Electronics Engineers, Electron Devices Society, Washington, DC, July 28-August 2, 2002. Responsible person, H. James Fincannon, organization code 6920, 216-433-5405.

12a. DISTRIBUTION/AVAILABILITY STATEMENT

12b. DISTRIBUTION CODE

Unclassified - Unlimited

Subject Category: 20

Distribution: Nonstandard

Available electronically at http://gltrs.grc.nasa.gov

This publication is available from the NASA Center for AeroSpace Information, 301-621-0390.

13. ABSTRACT (Maximum 200 words)

Accurate International Space Station (ISS) power prediction requires the quantification of solar array shadowing. Prior papers have discussed the NASA Glenn Research Center (GRC) ISS power system tool SPACE (System Power Analysis for Capability Evaluation) and its integrated shadowing algorithms. On-orbit telemetry has become available that permits the correlation of theoretical shadowing predictions with actual data. This paper documents the comparison of a shadowing metric (total solar array current) as derived from SPACE predictions and on-orbit flight telemetry data for representative significant shadowing cases. Images from flight video recordings and the SPACE computer program graphical output are used to illustrate the comparison. The accuracy of the SPACE shadowing capability is demonstrated for the cases examined.

\begin{tabular}{|c|c|c|}
\hline \multicolumn{3}{|c|}{$\begin{array}{l}\text { 14. SUBJECT TERMS } \\
\text { International Space Station; Power generation; Shadowing; Performance modeling; } \\
\text { Solar arrays }\end{array}$} \\
\hline $\begin{array}{l}\text { 17. SECURITY CLASSIFICATION } \\
\text { OF REPORT }\end{array}$ & $\begin{array}{l}\text { 18. SECURITY CLASSIFICATION } \\
\text { OF THIS PAGE }\end{array}$ & $\begin{array}{l}\text { 19. SECURITY CLASSIFICATION } \\
\text { OF ABSTRACT }\end{array}$ \\
\hline & Unclassified & Unclassified \\
\hline
\end{tabular}

NSN 7540-01-280-5500 15. NUMBER OF PAGES 16. PRICE CODE 20. LIMITATION OF ABSTRACT 